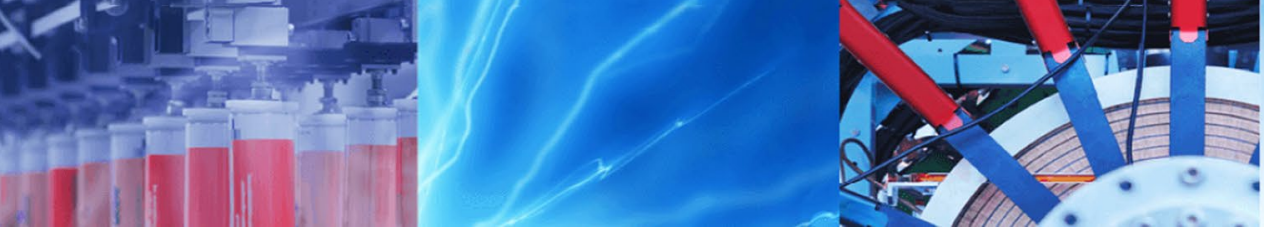

Research Article

\title{
Maximum power point tracking in photovoltaic systems under different operational conditions by using ZA-INC algorithm
}

\author{
Mohammadali Rajabi ${ }^{1}$. S. M. Hassan Hosseini ${ }^{1}$ (D)
}

Received: 25 May 2019 / Accepted: 17 October 2019 / Published online: 4 November 2019

(c) Springer Nature Switzerland AG 2019

\begin{abstract}
Today, environmental pollution has increased due to excess use of fossil resources. Amidst, renewable energy resources, solar energy is one of the infinite, clean and accessible options. Each solar cell has a unique operating point which is called maximum power point. Considering nonlinearity of $\mathrm{I}-\mathrm{V}$ and $\mathrm{P}-\mathrm{V}$ curves of Photovoltaic (PV) resources, their delivered power depends on operating point of the PV. That is, for changes in temperature or irradiation, some actions should be taken to obtain maximum operating point which is called maximum power point tracking (MPPT). This paper tries to configure power circuit using distributed maximum power point tracking (DMPPT) with a fly-back converter, optimize power and reduce fluctuations around maximum power point. MPPT is analyzed through simulation using P\&O, INC and zero fluctuation, adaptive step, increasing (ZA-INC) guidance algorithms in two steps including variable irradiation with constant temperature and variable temperature with constant irradiation using DMPPT and centralized MPPT. In DMPPT scheme using ZA-INC algorithm, power is optimized, losses are reduced, fluctuations around maximum power point are reduced, gain and tracking speed are increased.
\end{abstract}

Keywords Photovoltaic · MPPT · ZA-INC algorithm · Weather conditions · Flyback converter

\section{Introduction}

Today, environmental pollution has decreased due to renewable energy resources such as solar energy improved. PV systems have improved due to use of power electronic converters; that is why, such systems are so popular. Weak performance of PV systems under different operational conditions might be because of: shade of objects on solar panels, shading while sunset and sunrise, fault in generation process, aging and failure of solar panels, dust layer on panels, improper selection of solar panels' location, weather conditions, irradiation and temperature. Optimizing location of solar panels depends on mechanical factors and imposes heavy costs. Considering nonlinearity of $\mathrm{I}-\mathrm{V}$ and $\mathrm{P}-\mathrm{V}$ curves of $\mathrm{PV}$ source, their delivered power depends on operating point of the PV. That is, for changes in temperature or irradiation, some actions should be taken to obtain maximum operating point which is called MPPT [1, 2]. In summary, MPPT system has to determine operating point and adjust voltage and current of solar array to reach maximum power point. One of the low cost and effective methods for getting maximum power from $\mathrm{PV}$ is electrical tracking of maximum power point which tries to obtain maximum possible power from the cell under different weather conditions. In the following, studies on MPPT methods are reviewed briefly.

First class includes the methods which follow a basic algorithm among which perturbation and observation (P\&O), hill climbing $(\mathrm{HC})$ and incremental conductance (INC) can be mentioned [2, 3]. P\&O is based on creating perturbation on voltage and observing output power. If power is increased, perturbation is continued along the

S. M. Hassan Hosseini, smhh110@azad.ac.ir | 'Department of Electrical Engineering, South Tehran Branch, Islamic Azad University, Tehran, Iran. 
same path and if power is decreased, perturbation is reversed. This class tracks maximum power point without requiring parameters of the solar cell. Main disadvantage of this class is fluctuations around maximum power point and low tracking speed $[2,4-6]$.

Second class includes the methods based on modelling solar cell. These methods are designed and implemented through modelling solar cell and establishing relationships governing the model. Main disadvantage of this class is that they are not flexible, if a solar cell is replaced with another cell. Such that each implementation is specific to one type of solar cells which it has been designed. In addition, finding the model and parameters of the solar cell before designing is another problem $[7,8]$.

Third class includes the methods based on relationship between operating point and parameters of the solar cell among which two mentioned methods can be named. Method which employs linear relationship between short circuit current and operating point. Another method called open circuit voltage employs linear relationship between voltage of operating point and open voltage of the cell. Shortcoming of this class is that effect of variations in temperature and irradiation is not considered [9].

Fourth class includes the intelligent control methods among which fuzzy logic control and artificial neural networks can be mentioned. Intelligent methods require modeling solar cell which limits using control systems in the designed solar cell. In other words, it cannot be ensured that it performs well under glide gradient and its efficiency depends on knowledge and ability of the design [10-14].

In general, there are different measures for selecting a MPPT system which include manufacturing cost, gain factor, tracking speed, accuracy of the power point and simple implementation. Each method which can deliver maximum power from the solar cell is better and more efficient. So, best converter and MPPT algorithm which has lower fluctuations, higher tracking speed and higher gain factor compared to previous algorithms should be selected.

The contribution of this paper is ZA-INC method in two cases (CMPPT and DMPPT). It should be noted that from simulation results advantages of DMPPT include isolation, loss reduction, power increase, gain coefficient increase, simple implementation, voltage increase using flyback converter and using the same algorithm for all modules. MPPT is simulated using P\&O, INC and ZA-INC algorithm under two conditions: (1) variable irradiation with constant temperature, (2) variable temperature with constant irradiation.

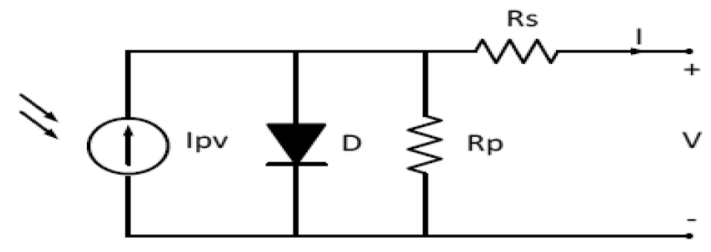

Fig. 1 equivalent circuit of the cell based on single-diode model

\section{Mathematical formulation of the PV cell}

Figure 1 shows equivalent circuit of the PV cell.

Current equation of the diode is obtained using Eq. (1) [15].

$I_{d}=I_{O}\left[\exp \left(\frac{Q V}{a K T}\right)-1\right]$

Subtracting $I_{d}$ from $I_{P V}$, Eq. (2) is obtained. In addition, Eq. (2) is used to draw I-V characteristic of the PV cell.

$I=I_{P V}-I_{O}\left[\exp \left(\frac{Q V}{a V_{T}}\right)-1\right]$

$I_{P V}$ is the light-dependent generated current, $I_{d}$ is diode current, $Q$ is electron charge, $I_{0}$ is leakage current or diode saturation current, $\mathrm{K}$ is Boltzmann constant $\left(1.38065 \times 10^{-23} \mathrm{~J} / \mathrm{K}\right), \mathrm{T}$ temperature of the $\mathrm{p}-\mathrm{n}$ junction (in Kelvin), $a$ is ideality constant.

Equation (2) can be used to obtain Eq. (3).

$I=I_{P V}-I_{O}\left[\exp \left(\frac{V+I R_{S}}{a V_{T}}\right)-1\right]-\left(\frac{V+I R_{S}}{R_{P}}\right)$

$R_{S}$ is equivalent series resistance of the array, $R_{p}$ is equivalent parallel resistance of the array.

Current generated by light in PV cell linearly depends on solar irradiation. The current generated by solar cell which is also affected by temperature is described using Eq. (4).

$I_{P V}=\left(I_{P V-S T C}+K_{i} \Delta T\right) \frac{G}{G_{S T C}}$

$T$ and $T_{n}$ are real temperature and nominal temperature in $K$, respectively. $G$ is irradiation on the surface, $G_{n}$ is nominal irradiation,

$\Delta T=T-T_{n}$

$\mathrm{I}_{\mathrm{o}}$ is saturation current of the diode and its dependency on temperature is described using Eq. (6).

$I_{O}=\frac{\left(I_{P V-S T C}+K_{i} \Delta T\right)}{\exp \left[\left(V_{\text {OS-STC }}+K_{V} \Delta T / a V_{T}\right)-1\right]}$ 
$V_{T}$ is thermal voltage, relationship between $R_{P}$ and $R_{S}$ in Eqs. (1)-(6) can be described using Eq. (7).

$R_{P}=\frac{V_{m P}+I_{m P} R_{S}}{I_{P V}-I_{O}\left[\exp \left(\frac{V_{m P}+I_{m P} R_{S}}{V_{T}}\right)+\exp \left(\frac{V_{m P}+I_{m P} R_{S}}{(P-1) V_{T}}\right)-2\right]-\frac{P_{\text {max }, E}}{V_{m P}}}$

$\mathrm{V}_{\mathrm{mp}}$ and $\mathrm{I}_{\mathrm{mp}}$ are voltage and current at MPP. Equation (7) indicates that for each $R_{p}$ there exists a $R_{S}$ for which maximum power point is obtained.

\section{MPPT control algorithms}

\subsection{P\&O control algorithm}

Main idea of $P \& O$ is that derivative of voltage with respect to power at maximum power point should be zero. Perturbing voltage of the array increases or decreases output power and gets close to maximum power point by keeping the next perturbation constant or reversing it. In this method, operating point of the module is obtained by changing duty cycle periodically, then new output power of the module is compared with its previous value to select suitable duty cycle for maximum power. Figure 2 shows flowchart of this algorithm $[1,3]$.

\subsection{Incremental conductance control algorithm}

This algorithm is used in systems which require high accuracy like aerospace industry. In this method, if $d p / d v$ is positive, the same direction is followed to reach Perturbing voltage of the array increases or decreases output power and gets close to maximum power point by keeping the next perturbation constant or reversing it in which $\mathrm{dp} / \mathrm{dv}$ is zero. If $\mathrm{dp} / \mathrm{dv}$ is negative, reverse direction should be followed to reach the intent point. Equation (8) presents three operating points of this algorithm.

$\left\{\begin{array}{c}\frac{\partial P}{\partial V}=0, V=V m p p \\ \frac{\partial P}{\partial V}>0, V<V m p p \\ \frac{\partial P}{\partial V}\langle 0, V\rangle V m p p\end{array}\right.$

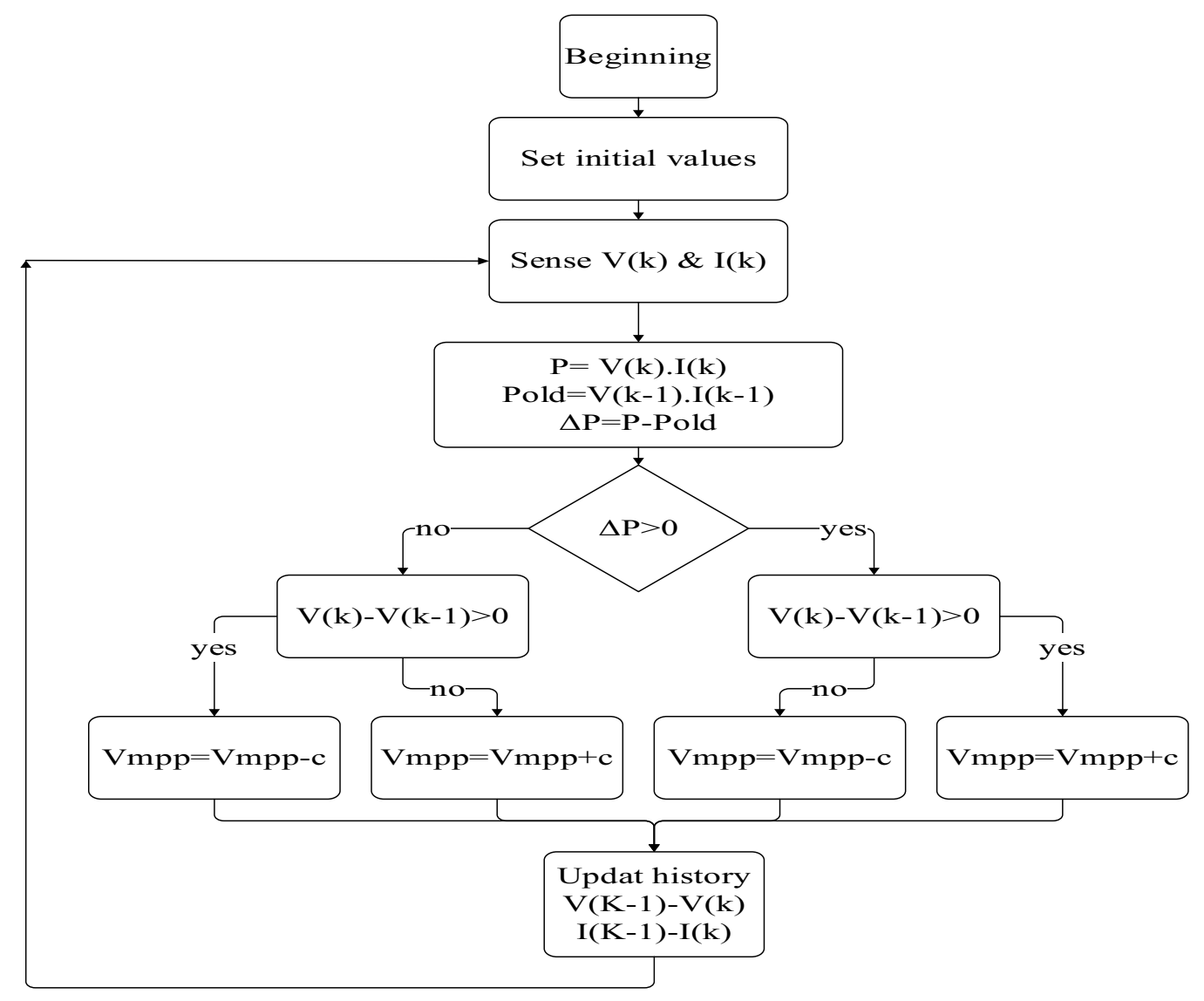

Fig. 2 P\&O algorithm 
Fig. 3 INC algorithm

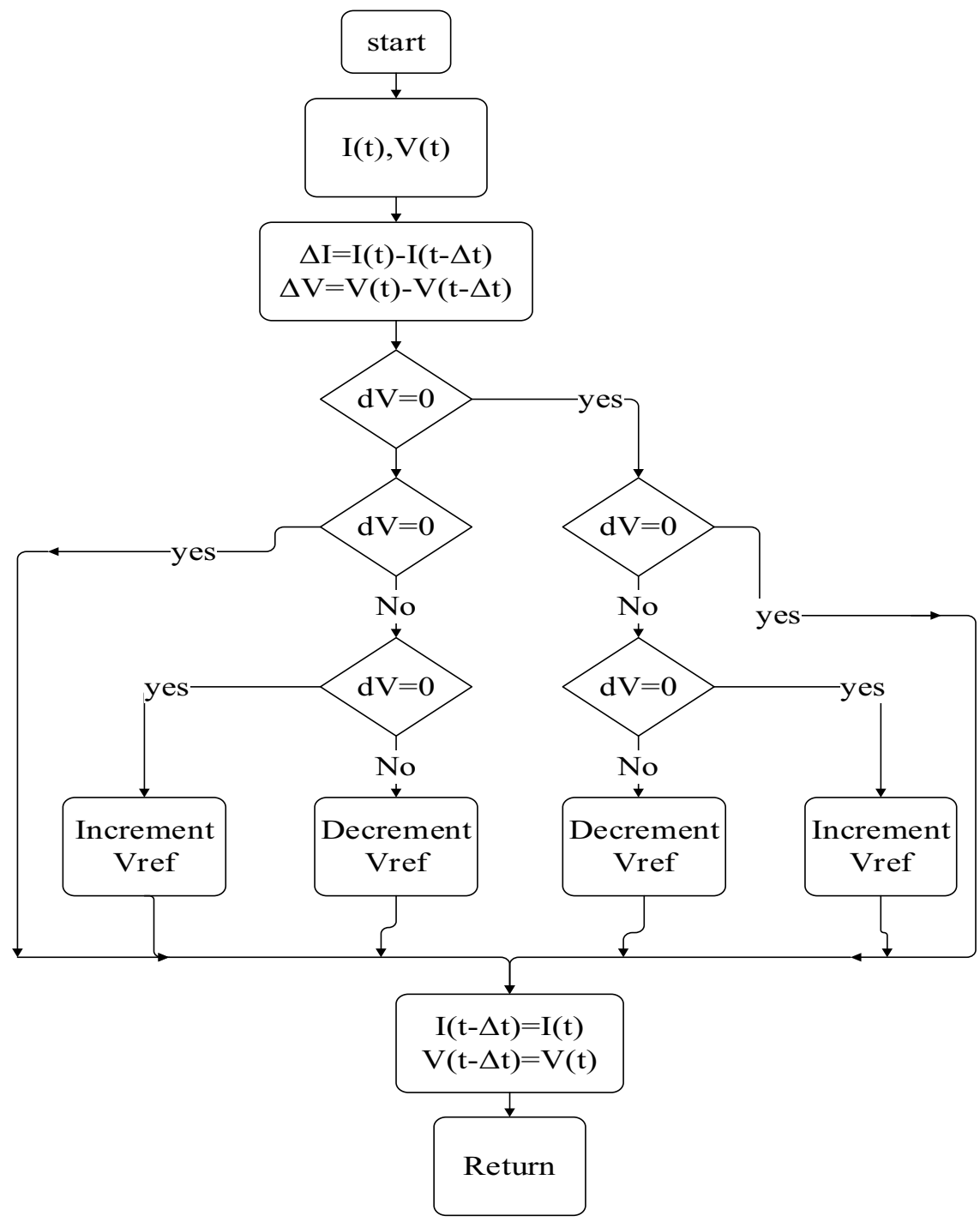

In other words, if changes of current and voltage are zero, reference voltage does not need to be increased or decreased. If voltage changes are zero when current changes are negative, reference voltage [3] should be reduced. Figure 3 shows flowchart of this algorithm.

\subsection{ZA-INC control algorithm (zero fluctuation, adaptive step, incremental conductance)}

In this method, movement step method is determined using irradiation changes. In ZA-INC algorithm, fluctuation around maximum power point is reduced, tracking speed and gain factor are increased compared to INC. ZA-INC adjust MPPT close to maximum power point well. It can be used in environmental changes. It allows the algorithm to track environmental or weather changes of the array, detect MPP and deliver maximum power to the load by creating an artificial perturbation. By weather changes which occur, exact step of MPPT is adjusted based on irradiation gradient. In determining adaptive step size, if irradiation gradient is decreased, MPPT algorithm should select a smaller step size to track maximum power point. If irradiation gradient is increased, MPPT should select a larger step size for MPPT [16, 17]. Flowchart of this algorithm is shown in Fig. 4.

\section{Fly-back converter}

Fly-back converter is one of the most applicable power electronic converters which is widely used in low and high powers. Popularity of flyback converter is due to its simple structure such that single-switch flyback converter is comprised of one switch, one diode, a transformer and a capacitance. Conversion density of flyback converter is higher than other converters at low powers because filter inductance is not used at the output. Simplest member of non-isolated converters family which has least number of 


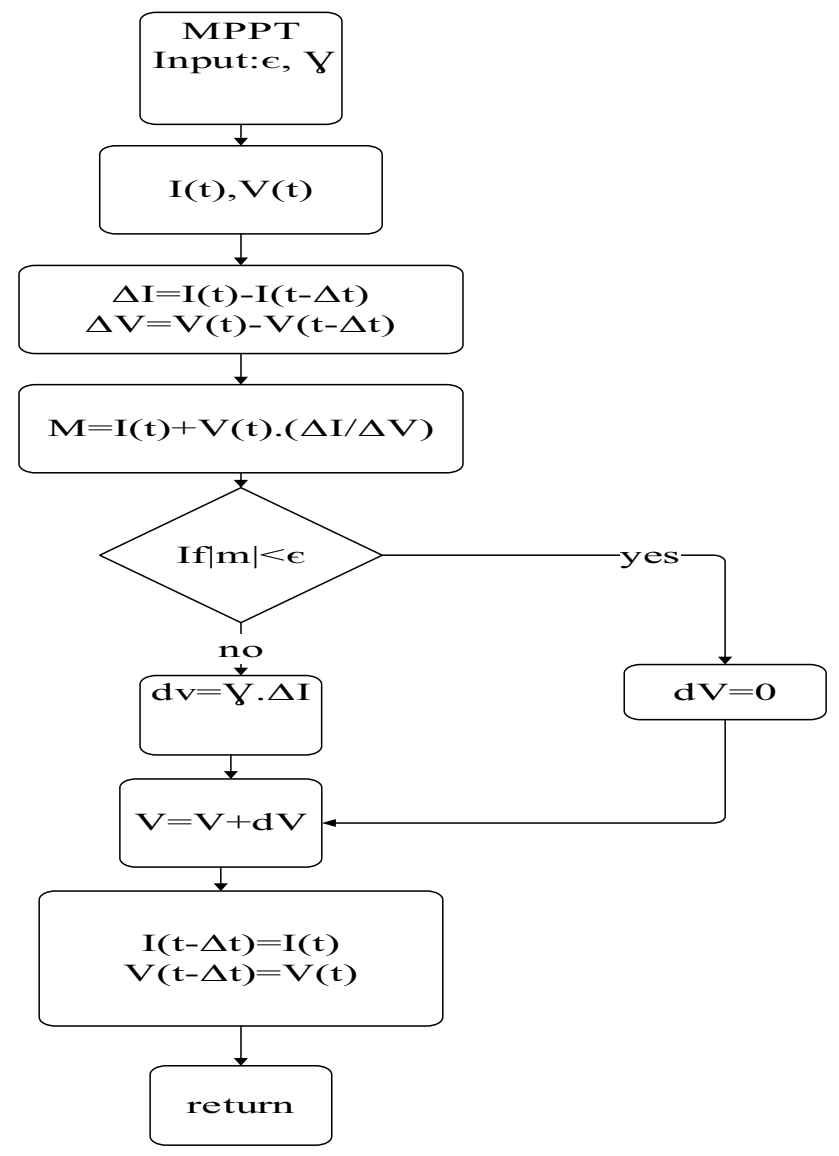

Fig. 4 ZA-INC algorithm

components is flyback converter which is used in a wide range of applications. Flyback converter is similar to boost converter except for an additional winding in the inductance which adds many capabilities to the circuit other than isolation including [18]:

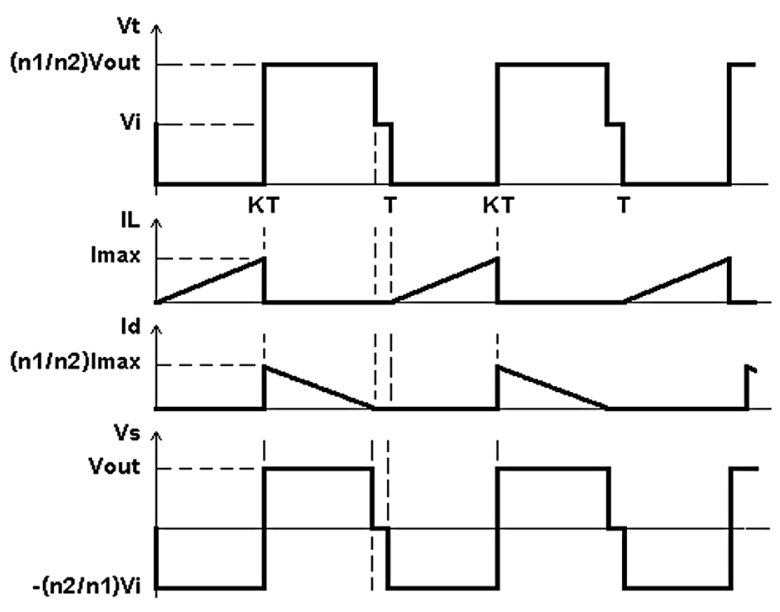

- More than one output.

- Output might be either positive or negative.

- Electric isolation between input and output is very high.

Performance of flyback converter is similar to buckboost converter; in a duty cycle when the switch is on, it becomes energized as current passes primary of the transformer and when the switch is off, energy is reduced by discharging energy in the load. Figure 5 shows flyback converter, its current and voltage [19].

If energy remains in the core till next half-cycle, operating mode continuous; if it does not remain, and operating mode is not continuous. When the switch is on, triangular linear current with $\mathrm{V}_{\text {in }} / \mathrm{L}_{1}$ slope passes the primary and continues until the switch is not turned off. When the switch is on, $V_{t}$ is equal to saturation voltage of the switch and when the switch is off this voltage reaches $V_{\text {in }}+\left(n_{1} / n_{2}\right) V_{\text {out }}$ (plus a diode drop and a transient state). When the switch is off, current in the secondary decreases with $\mathrm{V}_{\text {out }} / \mathrm{L}_{2}$ slope [20]. If flyback converter is put at output of the module, output voltage of the flyback converter is obtained using Eq. (9).

$V_{p v i}=K V_{\text {out }} \frac{d_{p v i}}{\left(1-d_{p v i}\right)}$

$K$ is conversion ratio of the flyback transformer, $d_{p v i}$ is switch's duty ratio for controlling flyback converter; as $d_{\text {pvi }}$ increases, $\mathrm{V}_{\text {pvi }}$ also increases [21].

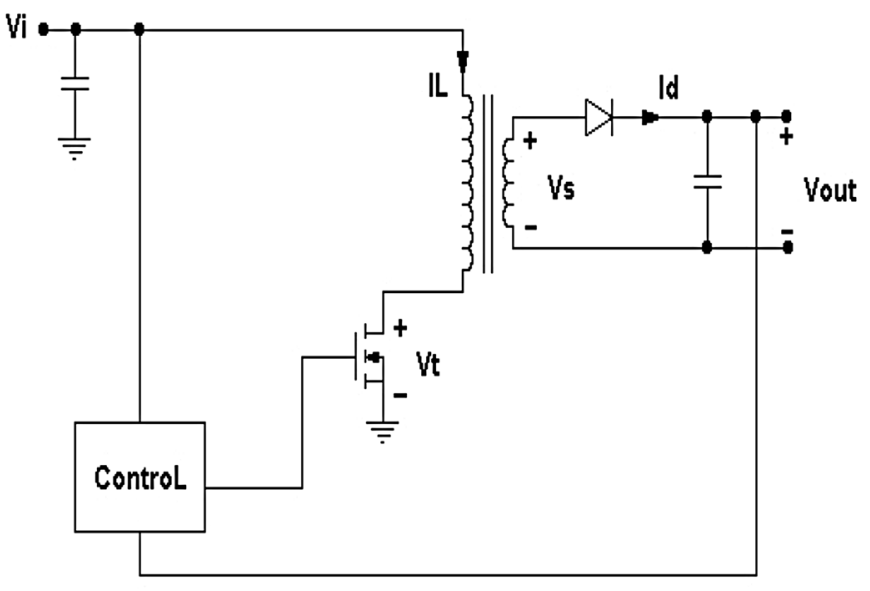

Fig. 5 Flyback converter and its currant and voltage 
Table 1 Electric characteristics of SX3200 W module under STC standard

\begin{tabular}{llll}
\hline Parameter & Module 1 & Module 2 & Module 3 \\
\hline $\mathrm{P}_{\mathrm{mpp}}$ & $200 \mathrm{~W}$ & $200 \mathrm{~W}$ & $200 \mathrm{~W}$ \\
Voltage at $\mathrm{P}_{\mathrm{mpp}}, \mathrm{V}_{\mathrm{mpp}}$ & $24.5 \mathrm{~V}$ & $24.5 \mathrm{~V}$ & $24.5 \mathrm{~V}$ \\
Current at $\mathrm{P}_{\mathrm{mmp}} \mathrm{I}_{\mathrm{mpp}}$ & $8.16 \mathrm{~A}$ & $8.16 \mathrm{~A}$ & $8.16 \mathrm{~A}$ \\
Open circuit voltage, $\mathrm{V}_{\mathrm{oc}}$ & $30.8 \mathrm{~V}$ & $30.8 \mathrm{~V}$ & $30.8 \mathrm{~V}$ \\
Short circuit current, $\mathrm{I}_{\mathrm{sc}}$ & $8.6 \mathrm{~A}$ & $8.6 \mathrm{~A}$ & $8.6 \mathrm{~A}$ \\
\hline
\end{tabular}

Table 2 Parameters required for simulation

\begin{tabular}{ll}
\hline Parameter & Value \\
\hline RC (in flyback) & $100 \mu \mathrm{F}, 0.01 \Omega$ \\
RC (out flyback) & $10 \mu \mathrm{F}, 0.01 \Omega$ \\
Magnetizing inductance (flyback) & $0.11937 \mathrm{H}$ \\
Input voltage (flyback) & $30 \mathrm{~V}$ \\
Output voltage (flyback) & $30 \mathrm{~V}$ \\
Power (flyback) & MPPT-700 W/ \\
& DMPPT- \\
& $200 \mathrm{~W}$ \\
Switching frequency load & $28.5 \mathrm{kHZ}$ \\
& $50 \Omega$ \\
\hline
\end{tabular}

\section{Parameters proposed for implementing the design}

Electric characteristics of SX3200W module under STC standard at $1000 \mathrm{~W} / \mathrm{m}^{2}$ intensity and $25{ }^{\circ} \mathrm{C}$ are represented in Table 1.

Parameters of flyback converter and load for simulation are represented in Table 2.

When irradiation intensity of the module is zero, module receives voltage from the network and the module is burnt; this problem is resolved using a diode. Flyback converter with unit conversion ratio is used to prevent collection of non-isolated voltages at one point and burning.

\section{Simulation results}

\subsection{Constant temperature with variable irradiation}

it can be seen in Fig. 6 that Maximum power point and current of the module with standard irradiation are according to standard of Table 1 but current and power of the module which its irradiation is 500 and $600 \mathrm{~W} / \mathrm{m}^{2}$ are reduced. Important point is that irradiation of the module is considered variable so that it is not optimized at one point and MPPT is described better in simulation. Table 3 represents results of curves in Fig. 6.

\subsection{Variable temperature and constant irradiation intensity}

Irradiation of all modules is $1000 \mathrm{~W} / \mathrm{m}^{2}$ at $25^{\circ} \mathrm{C}, 15^{\circ} \mathrm{C}$ and $35^{\circ} \mathrm{C}$. It can be inferred that MPP current in all three SX3200W modules is constant. Only MPP voltage changes
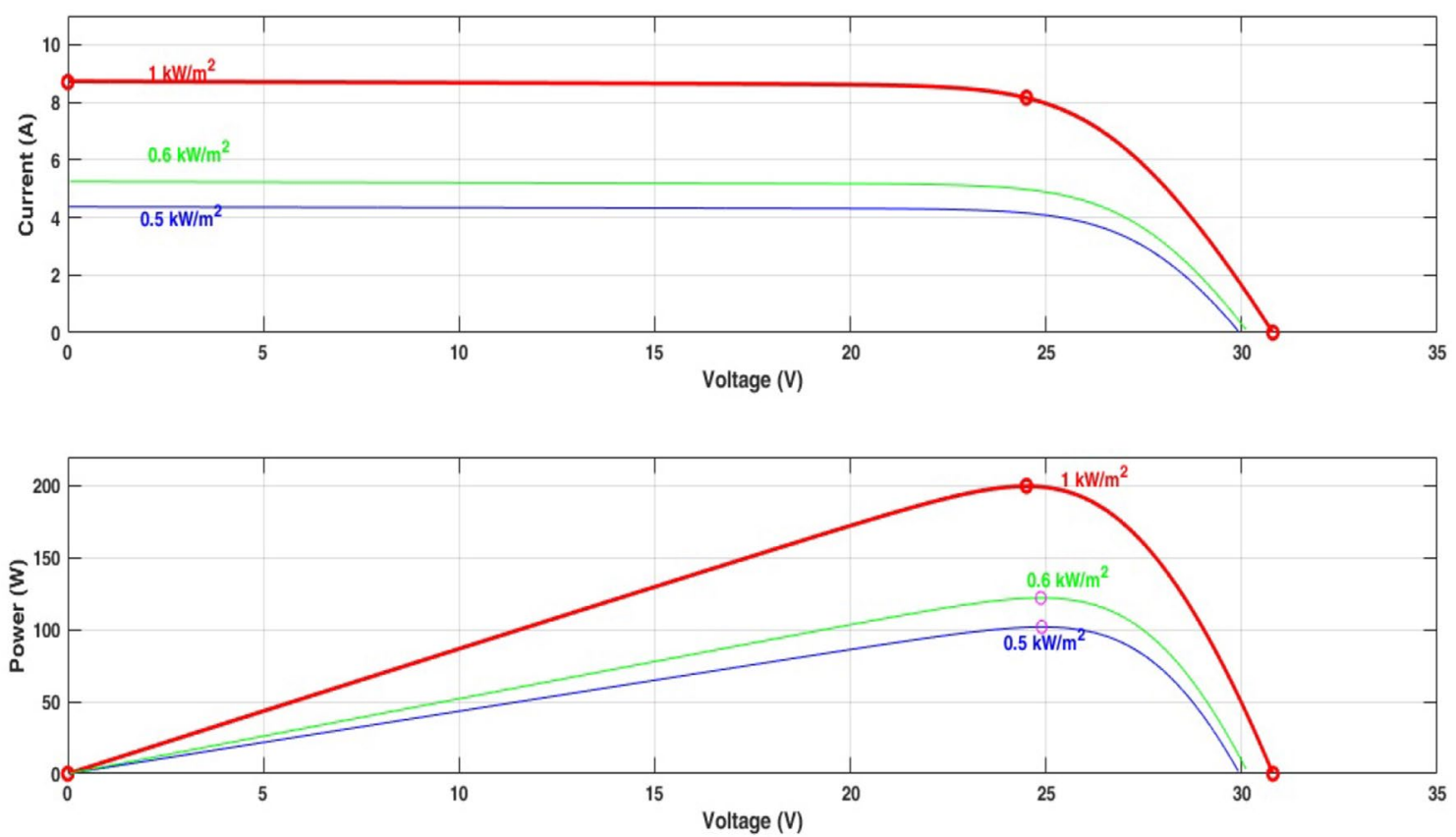

Fig. 6 Variations of current and power with respect to voltage of modules with variable irradiation intensity 
Table 3 Details of the three modules used for simulation in constant temperature and variable irradiation

\begin{tabular}{lllll}
\hline $\begin{array}{l}\text { Module at con- } \\
\text { stant tempera- } \\
\text { ture }\end{array}$ & $\begin{array}{l}\text { Irradia- } \\
\text { tion (W/ } \\
\left.\mathrm{m}^{2}\right)\end{array}$ & $\begin{array}{l}\text { Mpp } \\
\text { voltage } \\
(\mathrm{V})\end{array}$ & Mpp current (A) & $\begin{array}{l}\text { Mpp } \\
\text { power } \\
(\mathrm{W})\end{array}$ \\
\hline Module I & 1000 & 24.5 & 8.16 & 200 \\
Module 2 & 500 & 24.1 & 4.31 & 104 \\
Module 3 & 600 & 24.3 & 5.3 & 129 \\
\hline
\end{tabular}

a little. MPP power of all three modules is almost $200 \mathrm{~W}$. It should be mentioned that temperature is inversely proportional to power; in other words, if temperature is reduced, power is increased. This is shown in Table 4. Table 4 and Fig. 7 shows results of variable temperature and constant irradiation.

\subsection{Distributed maximum power point tracking}

Figure 8 shows configuration of the DMPPT power circuit simulated in MATLAB. In DMPPT strategy, each module applies its output voltage by a local DC-DC converter (flyback) in which each of the three modules (number of modules can be increased to $\mathrm{N}$ ) are connected to three fly-back converters (number of modules can be increased to N). Local DC-DC converter is considered for all modules so that these modules operate at maximum power point. In this scheme, a MPPT with the same algorithm is considered for all modules so that DMPPT strategy is shown better.

Figures 9,10 and 11 show power of modules using P\&O algorithm at irradiation intensities of 1000,500 and $600 \mathrm{~W} / \mathrm{m}^{2}$ at $25^{\circ} \mathrm{C}$. As can be seen, fluctuations around MPP are high and tracking speed is reduced. P\&O algorithm tracks perturbation created at the output of MPPT to see if they are positive or negative; if power is increased, it goes up one step and if power is reduced, it returns. Therefore, P\&O fluctuates around three points.

Figures 12,13 and 14 show power of modules using INC at variable irradiation intensities of 1000,500 and $600 \mathrm{~W} / \mathrm{m}^{2}$ at $25^{\circ} \mathrm{C}$. Power obtained from INC algorithm
Table 4 simulation details of the three modules (variable temperature and constant irradiation intensity)

\begin{tabular}{lllll}
\hline $\begin{array}{l}\text { Module at constant } \\
\text { irradiation }\end{array}$ & $\begin{array}{l}\text { Temperature of the } \\
\text { module }\end{array}$ & Mpp voltage $(\mathrm{V})$ & Mpp current $(\mathrm{A})$ & $\begin{array}{l}\text { Mpp } \\
\text { power } \\
(\mathrm{W})\end{array}$ \\
\hline Model 1 & 25 & 24.5 & 8.16 & 200 \\
Model 2 & 15 & 25.74 & 8.16 & 210 \\
Model 3 & 35 & 23.9 & 8.16 & 195 \\
\hline
\end{tabular}
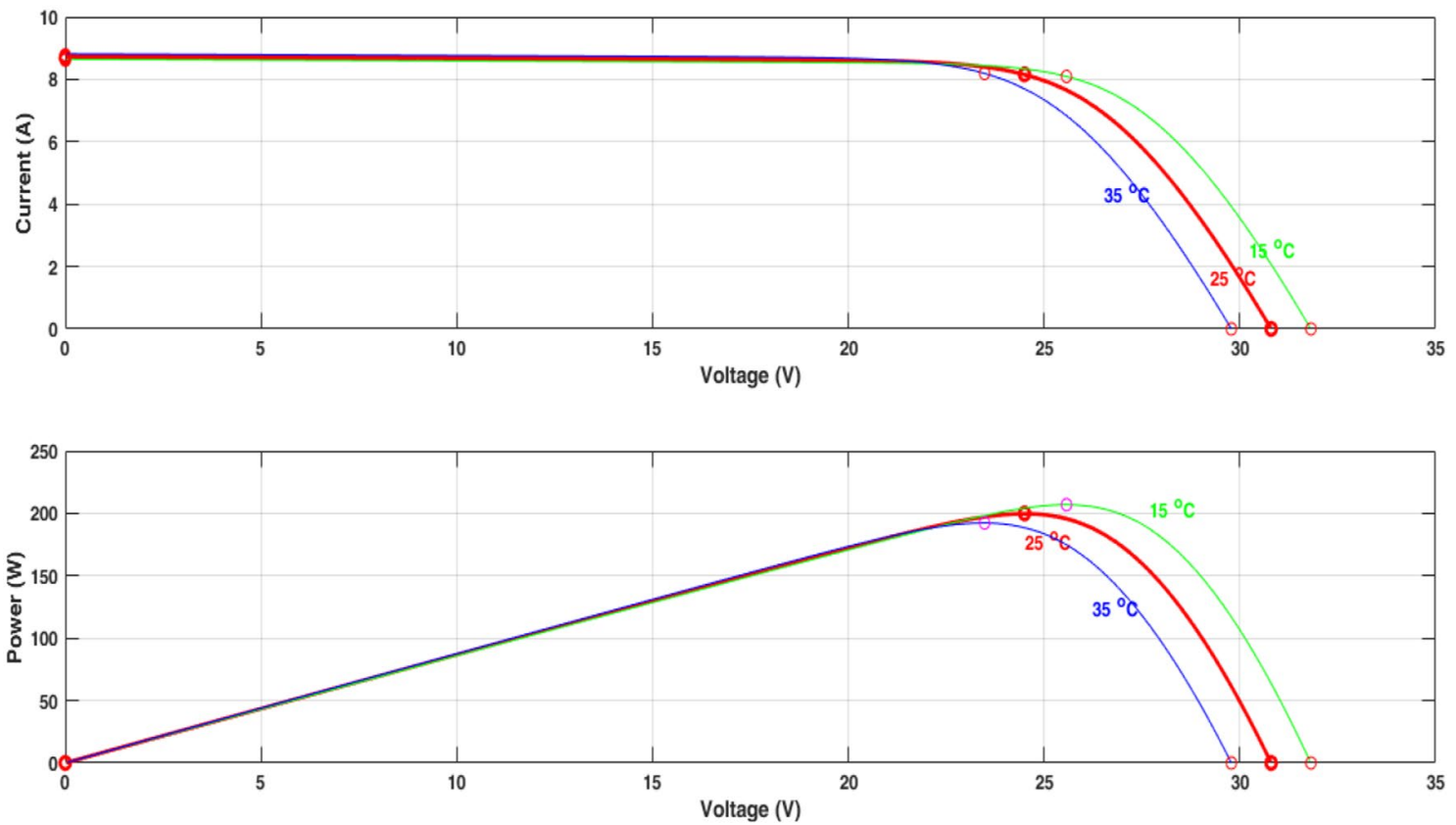

Fig. 7 Variations of current and power versus voltage of modules with variable temperature 


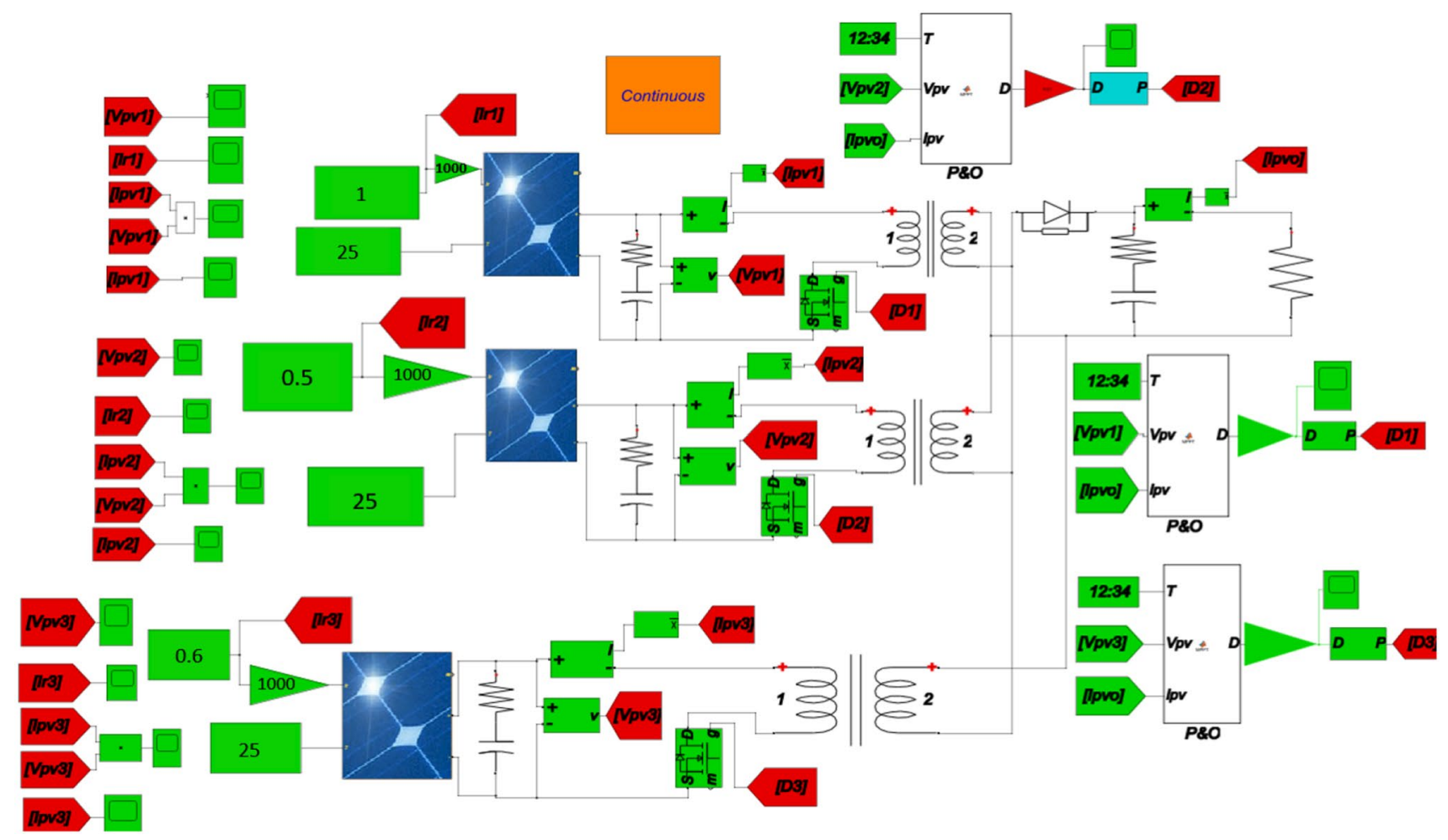

Fig. 8 Fly-back converter of DMPPT scheme in Simulink

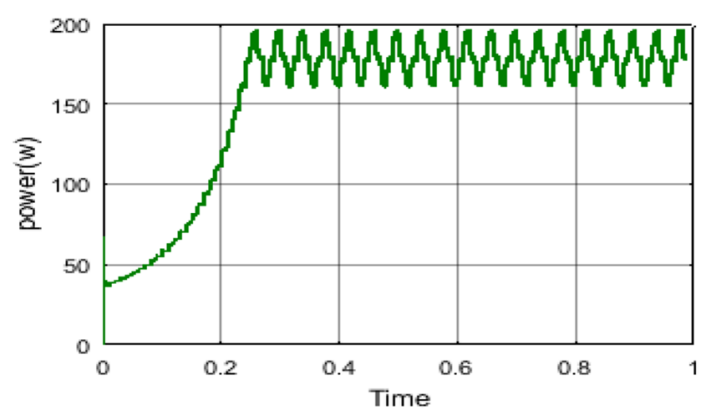

Fig. 9 Output power of module 1 using P\&O with variable irradiation $\left(1000 \mathrm{~W} / \mathrm{m}^{2}\right)$ and constant temperature

is higher than the power obtained from $\mathrm{P} \& \mathrm{O}$ and it tracks maximum power point with higher speed and accuracy.

Figures 15, 16 and 17 show power of modules using ZA-INC at variable irradiation intensities of 1000,500 and $600 \mathrm{~W} / \mathrm{m}^{2}$ at $25^{\circ} \mathrm{C}$. As can be seen, fluctuations around MPP is reduced compared to P\&O and INC and tracking speed is increased significantly. In addition, obtained power is also increased.

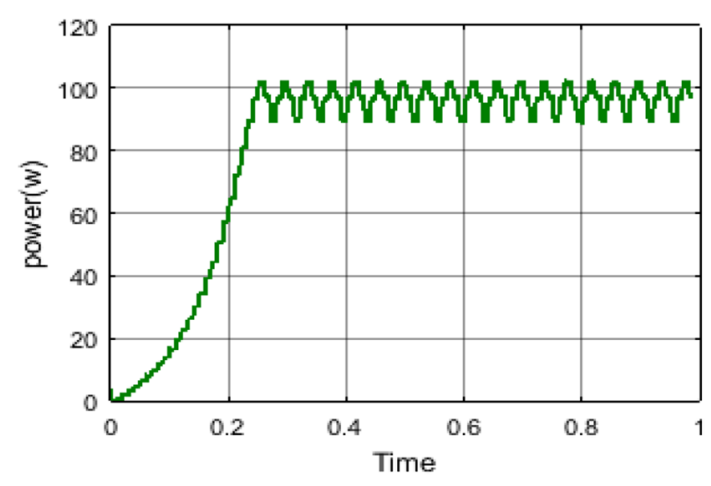

Fig. 10 Output power of module 2 using P\&O with variable irradiation $\left(500 \mathrm{~W} / \mathrm{m}^{2}\right)$ and constant temperature

Figures 18,19 and 20 show power of modules using $\mathrm{P} \& \mathrm{O}$ at constant irradiation intensity of $1000 \mathrm{~W} / \mathrm{m}^{2}$ with variable temperatures of 25,15 and $35^{\circ} \mathrm{C}$. When temperature is variable and irradiation is constant, output power is inversely proportional to temperature; if temperature is decreased, power increases. This algorithm is better than INC under variable temperatures. In other words, 


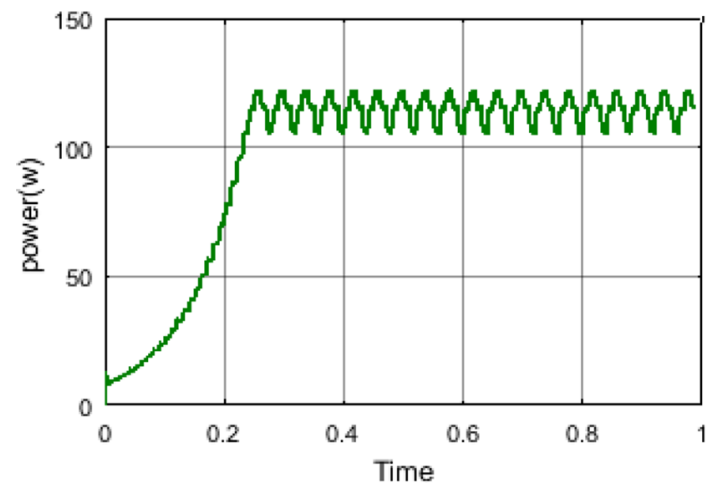

Fig. 11 Output power of module 3 using $P \& O$ with irradiation $\left(600 \mathrm{~W} / \mathrm{m}^{2}\right)$ and constant temperature

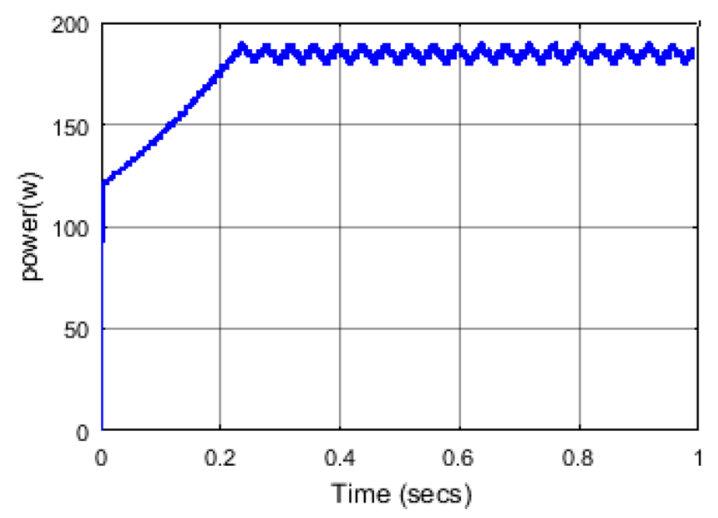

Fig. 12 Output power of module 1 using INC with variable irradiation intensity and constant temperature

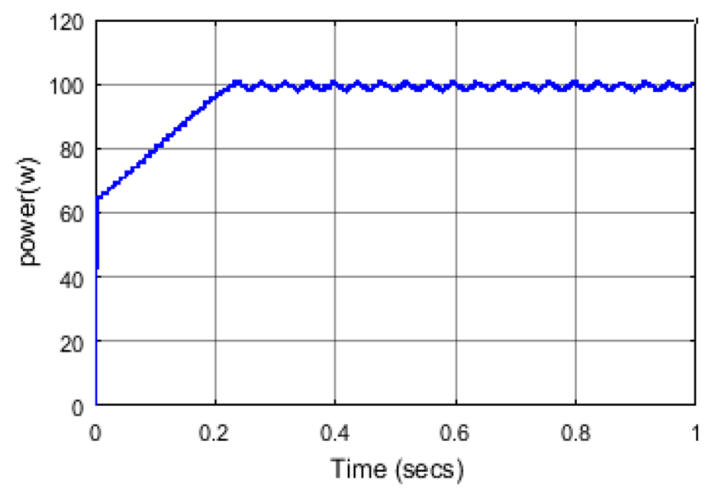

Fig. 13 Output power of module 2 using INC with variable irradiation intensity and constant temperature

fluctuations around maximum power point are reduced. But tracking speed is reduced compared to variations of irradiation intensity using the same algorithm.

Figures 21, 22 and 23 show power of modules using INC algorithm under constant irradiation of $1000 \mathrm{~W} / \mathrm{m}^{2}$ with

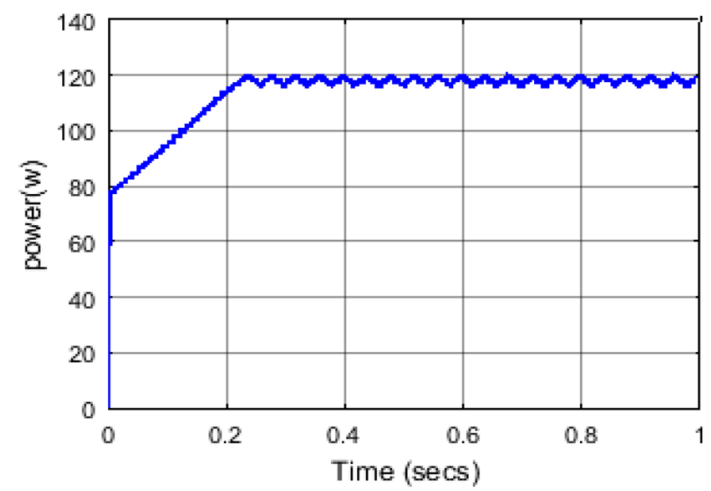

Fig. 14 Output power of module 3 using INC with variable irradiation intensity and constant temperature

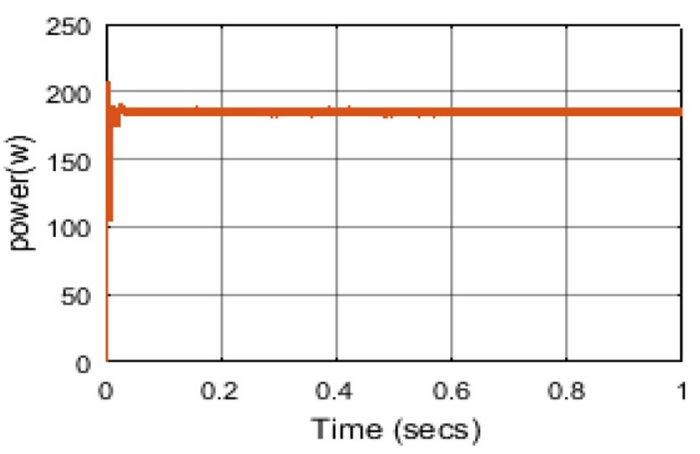

Fig. 15 Output power of module 1 using ZA-INC with variable irradiation intensity and constant temperature

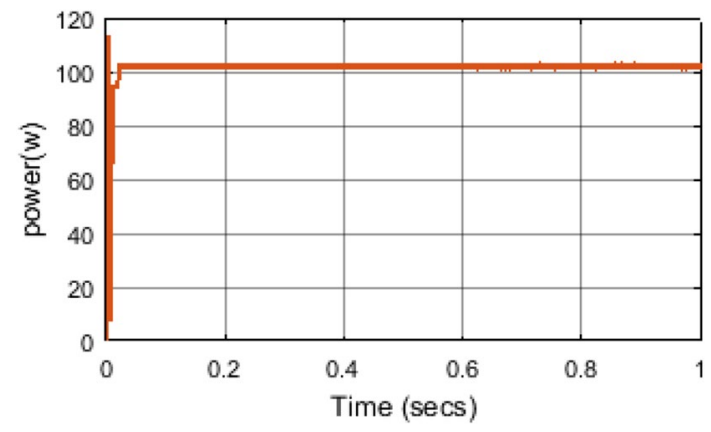

Fig. 16 Output power of module 2 using ZA-INC with variable irradiation intensity and constant temperature

variable temperatures of 25,15 and $35^{\circ} \mathrm{C}$. As can be seen, fluctuations are increased and tracking speed is decreased compared to variable irradiation. Power obtained from INC under variable temperature is increased but its shortcoming is fluctuations around MPP and low tracking speed in variable temperature. 


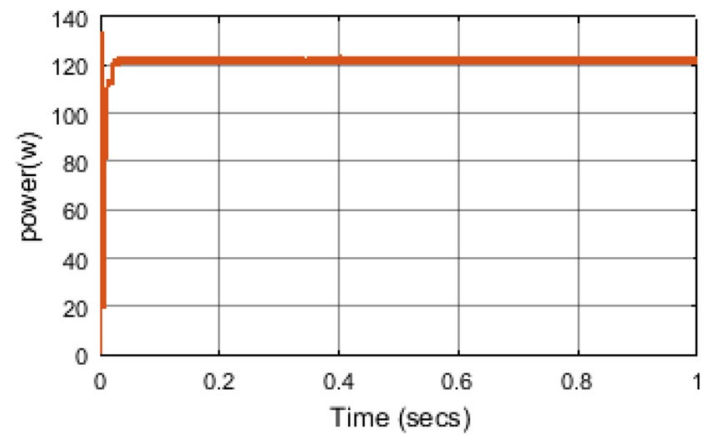

Fig. 17 Output power of module 3 using ZA-INC with variable irradiation intensity and constant temperature

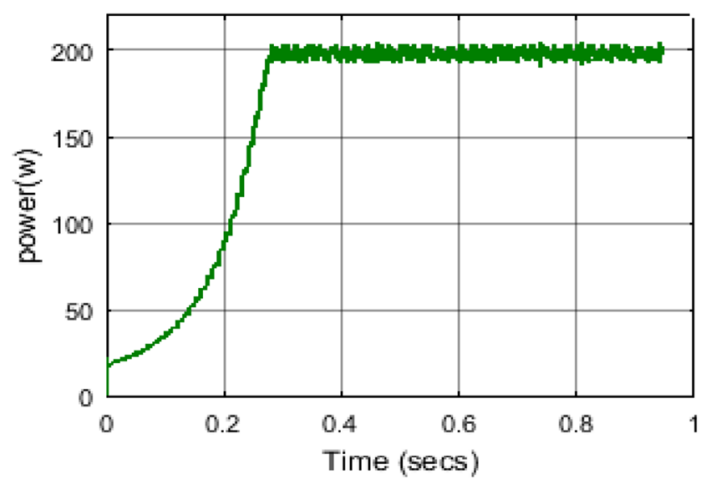

Fig. 18 Output power of module 1 using P\&O with variable temperature and constant irradiation

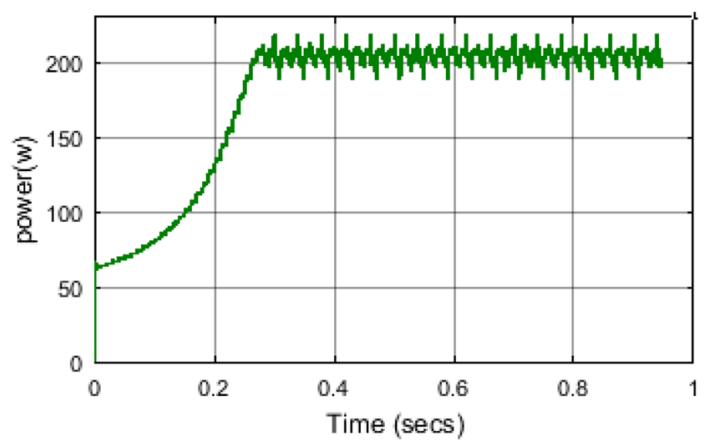

Fig. 19 Output power of module 2 using P\&O with variable temperature and constant irradiation

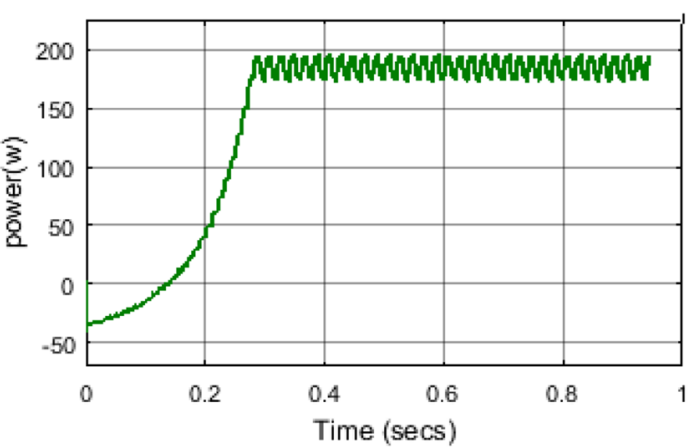

Fig. 20 Output power of module 3 using $P \& O$ with variable temperature and constant irradiation

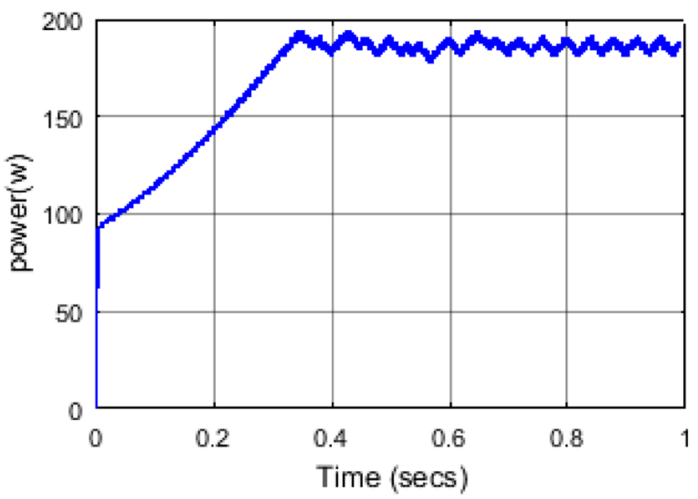

Fig. 21 Output power of module 1 using INC with variable temperature and constant irradiation

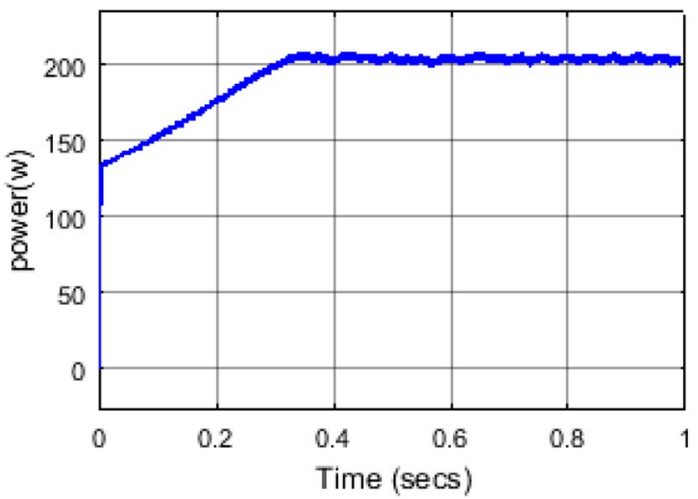

Fig. 22 Output power of module 2 using INC with variable temperature and constant irradiation 


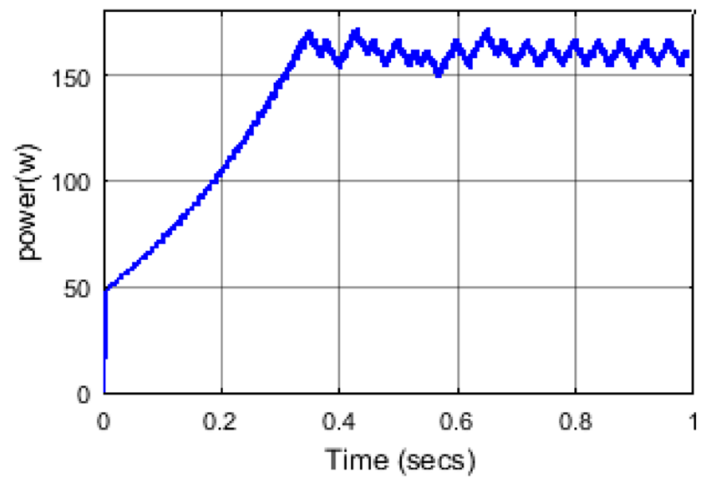

Fig. 23 Output power of module 3 using INC with variable temperature and constant irradiation

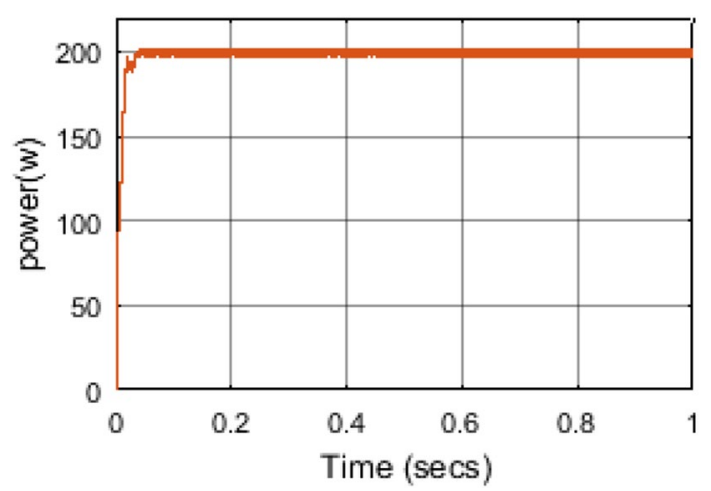

Fig. 24 Output power of module 1 using ZA-INC with variable temperature and constant irradiation

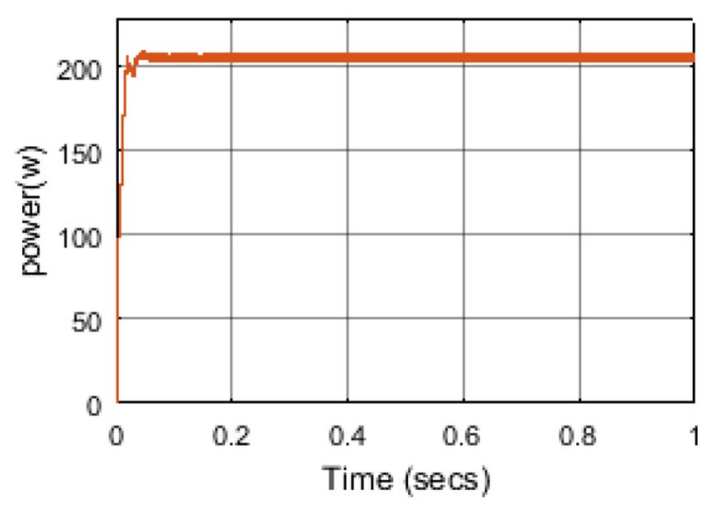

Fig. 25 Output power of module 2 using ZA-INC with variable temperature and constant irradiation

Figures 24,25 and 26 show power of modules using ZA-INC at constant irradiation intensity of $1000 \mathrm{~W} / \mathrm{m}^{2}$ with variable temperatures of 25,15 and $35^{\circ} \mathrm{C}$. Fluctuations around maximum power point are reduced,

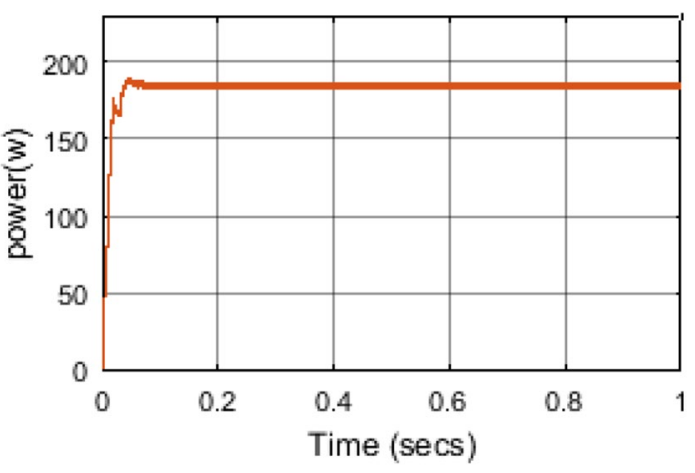

Fig. 26 Output power of module 3 using ZA-INC with variable temperature and constant irradiation

tracking speed is increased and obtained power is increased a little. It can be inferred that shortcomings of other two algorithms are resolved in this algorithm and it responds better under changing environmental conditions.

\subsection{Centralized maximum power point tracking}

Figure 27 shows configuration of centralized MPPT circuit simulated using MATLAB. In this scheme, modules apply their output voltage using a local converter in which three modules (number of modules can be increased to $\mathrm{N}$ ) are connected to a fly-back module (local DC-DC converter); that is, one local converter is considered for all modules, so that these modules operate at maximum power point.

Figure 28 shows output power of modules with constant temperature of $25^{\circ} \mathrm{C}$ and irradiation intensities of 1000,500 and $600 \mathrm{~W} / \mathrm{m}^{2}$ using $\mathrm{P} \& \mathrm{O}$ algorithm. As can be seen, losses are increased and power is decreased compared to DMPPT. Although MPPT and cost are decreased but gain factor is decreased. Compared to DMPPT using the same algorithm, fluctuations around maximum power point are increased and tracking speed is decreased which shows superiority of DMPPT.

Figure 29 shows power of modules at constant temperature of $25^{\circ} \mathrm{C}$ and irradiation intensities of 1000,500 and $600 \mathrm{~W} / \mathrm{m}^{2}$ using INC algorithm. Power obtained using INC is better than that obtained using $P \& O$ and it tracks maximum power point with better accuracy; fluctuations around maximum power point are reduced. Obtained power and tracking speed are reduced compared to DMPPT which shows superiority of DMPPT.

Figure 30 shows output power of modules at constant temperature of $25^{\circ} \mathrm{C}$ and irradiation intensities of 1000 , 500 and $600 \mathrm{~W} / \mathrm{m}^{2}$ using ZA-INC algorithm. As can be seen, fluctuations around maximum power point are decreased compared to $\mathrm{P} \& \mathrm{O}$ and INC and tracking speed is increased. 


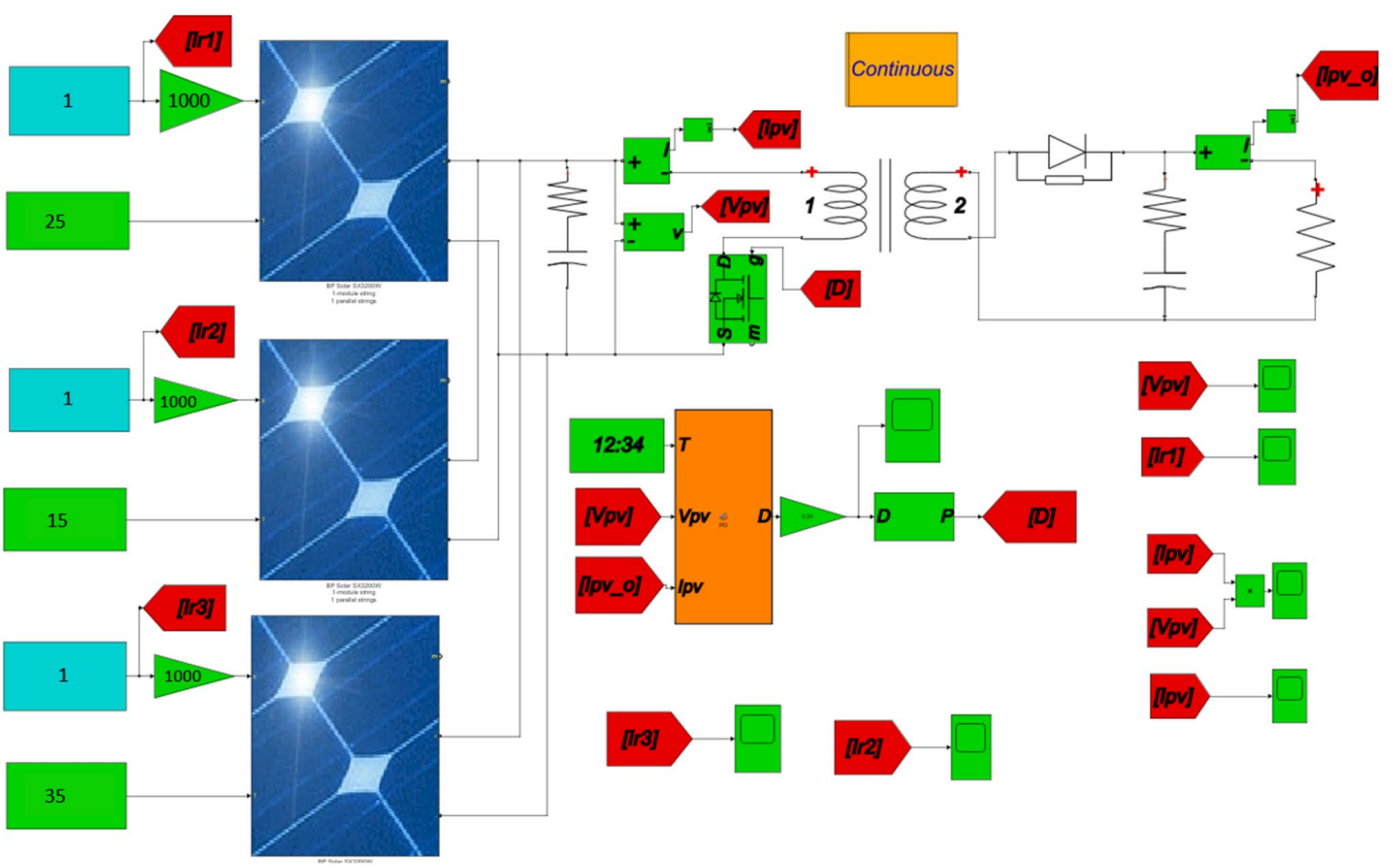

Fig. 27 Fly-back converter in centralized MPPT scheme in Simulink

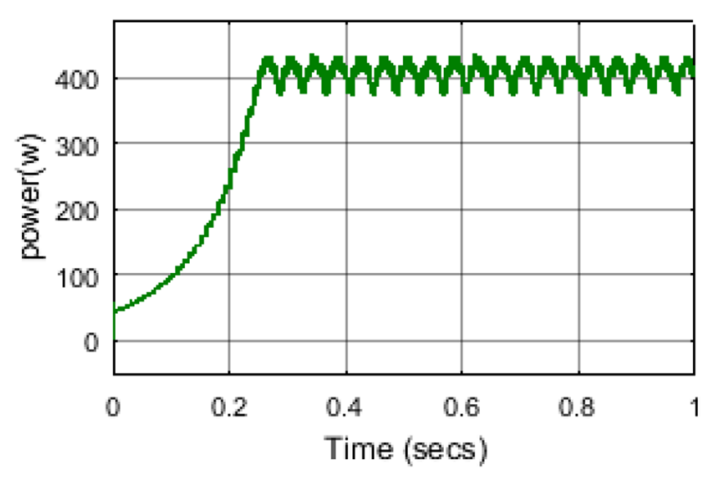

Fig. 28 Output power of modules using P\&O at constant temperature and variable irradiation intensity

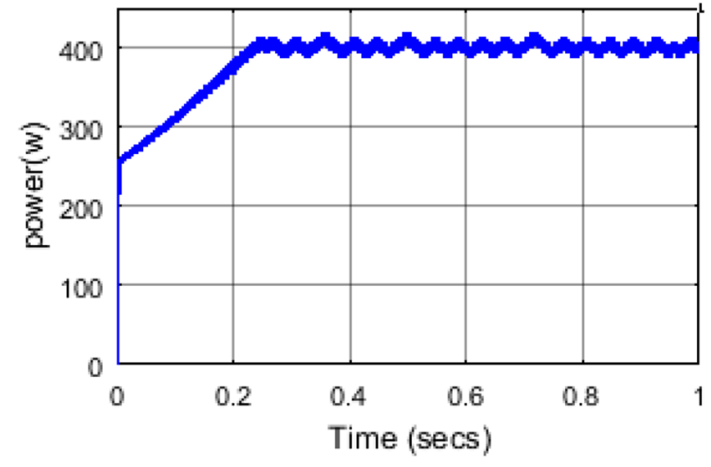

Fig. 29 Output power of modules using INC at constant temperature and variable irradiation intensity 


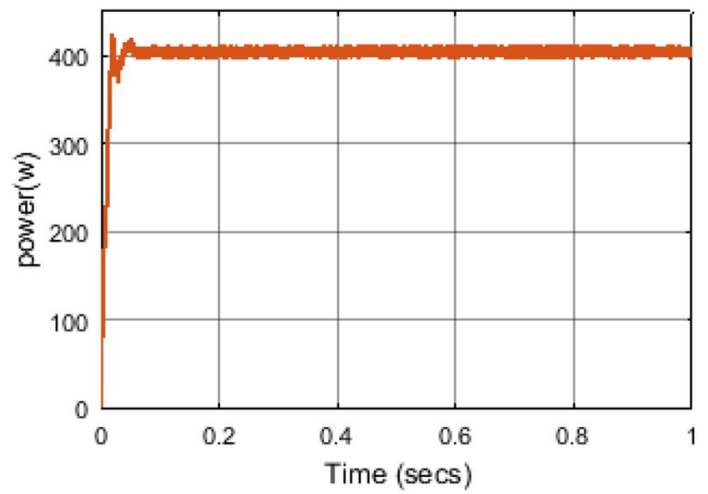

Fig. 30 Output power of modules using ZA-INC at constant temperature and variable irradiation intensity

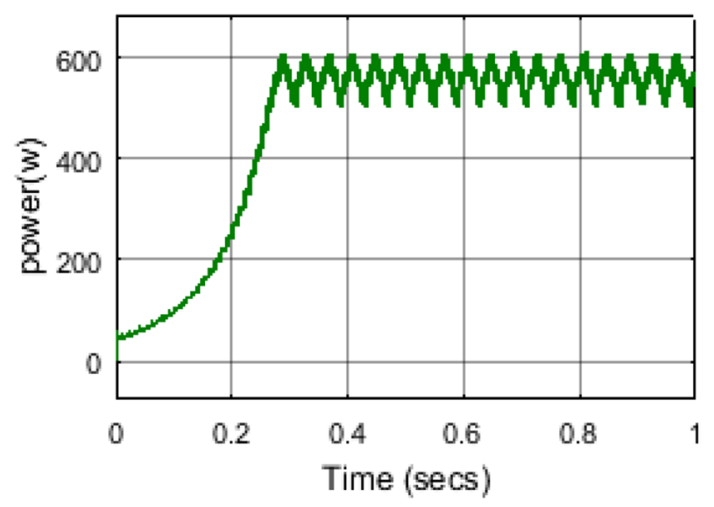

Fig. 31 Output power of modules using P\&O under constant irradiation and variable temperature

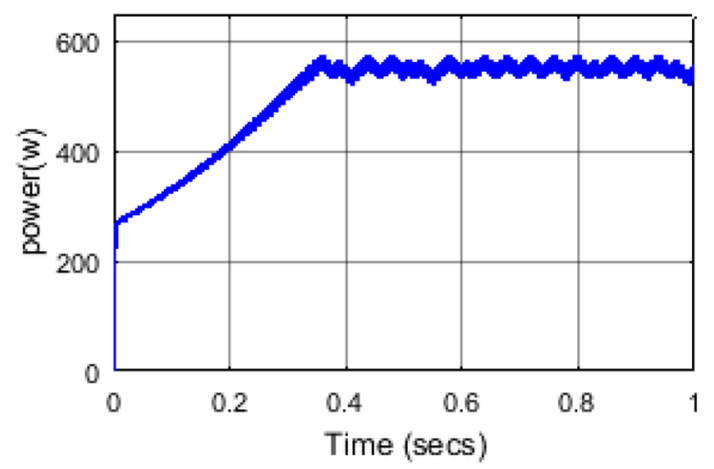

Fig. 32 Output power of modules using INC under constant irradiation intensity and variable temperature

In addition, power obtained is also increased a little, but Compared to DMPPT, power obtained decreased.

Figure 31 shows power of modules using $\mathrm{P} \& \mathrm{O}$ algorithm under constant irradiation of $1000 \mathrm{~W} / \mathrm{m}^{2}$ with variable temperatures of 25,15 and $35^{\circ} \mathrm{C}$. This algorithm performs better than INC under variable temperature; in

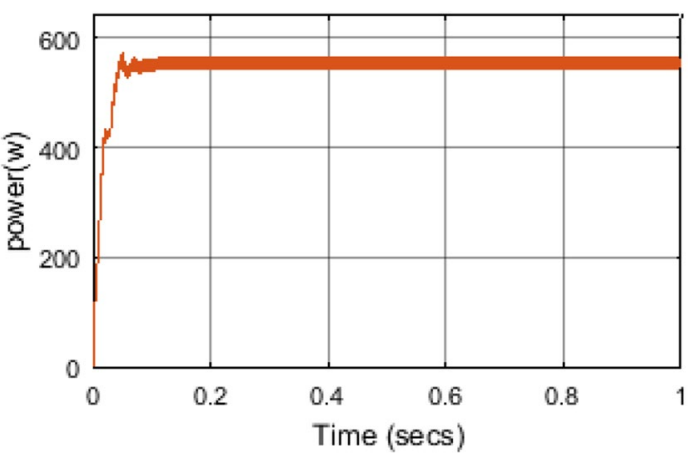

Fig. 33 Output power of modules using ZA-INC algorithm under constant irradiation and variable temperature

other words, fluctuations around maximum power point are reduced. But, tracking speed is decreased compared to this algorithm under variable irradiation intensity.

Figure 32 shows output power of modules using INC algorithm under constant irradiation of $1000 \mathrm{~W} / \mathrm{m}^{2}$ with variable temperatures of 25,15 and $35^{\circ} \mathrm{C}$. Variations of temperature increase fluctuations and tracking speed versus irradiation intensity is decreased. This algorithm does not perform MPPT well under variable temperature. Obtained power and tracking speed are decreased compared to DMPPT.

Figure 33 shows output power of modules under constant irradiation of $1000 \mathrm{~W} / \mathrm{m}^{2}$ with variable temperatures of 25,15 and $35^{\circ} \mathrm{C}$ using ZA-INC algorithm. Fluctuations around maximum power point are reduced, tracking speed and obtained power are increased. It can be inferred that disadvantages of other two algorithms are resolved in this algorithm and its responds better under weather changes. But, compared to DMPPT, it has some fluctuations around maximum power point; obtained power and tracking speed are decreased which indicates superiority of DMPPT.

Table 5 shows simulation results under constant temperature and variable irradiation and Table 6 shows simulation results under constant irradiation and variable temperature. As can be inferred from the tables, using ZA-INC in DMPPT increases obtained power, reduces fluctuations around maximum power point and improves tracking speed. Under variable temperature, $\mathrm{P} \& \mathrm{O}$ algorithm performs better than two other algorithms which becomes even better in centralized MPPT. Least tracking speed under variable temperature is obtained using INC.

\section{Conclusion}

Advantages of DMPPT include isolation, loss reduction, power increase, gain coefficient increase, simple implementation, voltage increase using flyback converter and 
Table 5 Analysis of trackers under constant temperature and variable irradiation

\begin{tabular}{|c|c|c|c|c|c|c|c|c|c|}
\hline $\begin{array}{l}\text { Scheme with } \\
\text { constant tem- } \\
\text { perature }\end{array}$ & Algorithm & Reliability & Cost & $\begin{array}{l}\text { Delivered } \\
\text { power } \\
\text { (W) }\end{array}$ & Real value (W) & $\begin{array}{l}\text { Gain factor } \\
(\%)\end{array}$ & $\begin{array}{l}\text { Recovery time } \\
\text { (s) }\end{array}$ & $\begin{array}{l}\text { Fluctuations } \\
\text { around maxi- } \\
\text { mum power } \\
\text { point (W) }\end{array}$ & $\begin{array}{l}\text { Number of } \\
\text { current and } \\
\text { voltage sen- } \\
\text { sors }\end{array}$ \\
\hline DMPPT & $\mathrm{P} \& \mathrm{O}$ & Low & High & 402 & 433 & 92.8 & 0.24 & 46 & 7 \\
\hline DMPPT & INC & Low & High & 408 & 433 & 94.2 & 0.20 & 15 & 7 \\
\hline DMPPT & ZA-INC & Low & High & 412 & 433 & 95.1 & 0.035 & 10 & 7 \\
\hline MPPT & $\mathrm{P} \& \mathrm{O}$ & High & Low & 385 & 433 & 89 & 0.25 & 60 & 3 \\
\hline MPPT & INC & High & Low & 395 & 433 & 91.2 & 0.23 & 21 & 3 \\
\hline MPPT & ZA-INC & High & Low & 400 & 433 & 92.3 & 0.04 & 15 & 3 \\
\hline
\end{tabular}

Table 6 Analysis of trackers under constant irradiation and variable temperature

\begin{tabular}{|c|c|c|c|c|c|c|c|c|c|}
\hline $\begin{array}{l}\text { Scheme with } \\
\text { constant irradia- } \\
\text { tion }\end{array}$ & Algorithm & Reliability & Cost & $\begin{array}{l}\text { Delivered } \\
\text { power (W) }\end{array}$ & Real value $(\mathrm{W})$ & Gain factor (\%) & $\begin{array}{l}\text { Recov- } \\
\text { ery time } \\
\text { (s) }\end{array}$ & $\begin{array}{l}\text { Fluctuations } \\
\text { around maxi- } \\
\text { mum power } \\
\text { point (W) }\end{array}$ & $\begin{array}{l}\text { Number of cur- } \\
\text { rent and voltage } \\
\text { sensors }\end{array}$ \\
\hline DMPPT & $\mathrm{P} \& \mathrm{O}$ & Low & High & 570 & 605 & 94.2 & 0.26 & 47 & 7 \\
\hline DMPPT & INC & Low & High & 578 & 605 & 95.5 & 0.32 & 25 & 7 \\
\hline DMPPT & ZA-INC & Low & High & 584 & 605 & 96.5 & 0.05 & 12 & 7 \\
\hline $\mathrm{P} \& \mathrm{O}$ & MPPT & High & Low & 550 & 605 & 90 & 0.28 & 76 & 3 \\
\hline MPPT & INC & High & Low & 560 & 605 & 92.5 & 0.35 & 40 & 3 \\
\hline MPPT & ZA-INC & High & Low & 568 & 605 & 93.9 & 0.08 & 17 & 3 \\
\hline
\end{tabular}

using the same algorithm for all modules. In DMPPT, power of each module is almost maximum power point. Power obtained using INC algorithm is higher than P\&O algorithm and MPPT is performed with higher speed and accuracy under variable irradiation intensity. When temperature varies, power delivered by the array is inversely proportional to the temperature; in such condition, $\mathrm{P} \& \mathrm{O}$ reaches first maximum power point faster than INC. In ZA-INC, fluctuations around maximum power point are reduced, tracking speed is increased, efficiency is increased and MPPT is adjusted close to maximum power. ZA-INC can be used under environmental and weather changes.

\section{Compliance with ethical standards}

Conflict of interest On behalf of all authors, the corresponding author states that there is no conflict of interest.

\section{References}

1. Danandeh MA, Mousavi G (2018) Comparative and comprehensive review of maximum power point tracking methods for PV cells. Renew Sustain Energy Rev 82:2743-2767
2. Dadfar S, Wakil K, Khaksar M, Rezvani A, Miveh MR, Gandomkar M (2019) Enhanced control strategies for a hybrid battery/photovoltaic system using FGS-PID in grid-connected mode. Int J Hydrog Energy 44(29):14642-14660

3. Rezvani A, Khalili A, Mazareie A, Gandomkar M (2016) Modeling, control, and simulation of grid connected intelligent hybrid battery/photovoltaic system using new hybrid fuzzy-neural method. ISA Trans 63:448-460

4. Esram T, Chapman PL (2007) Comparison of photovoltaic array maximum power point tracking techniques. IEEE Trans Energy Convers 22(2):439-449

5. Piegari L, Rizzo R (2010) Adaptive perturb and observe algorithm for photovoltaic maximum power point tracking. IET Renew Power Gener 4:317-328

6. Femia N, Granozio D, Petrone G, Spagnuolo G, Vitelli M (2005) Optimization of perturb and observe maximum power point tracking method. IEEE Trans Power Electron 20:963-973

7. Mutoh N, Matuo T (2002) Prediction-data-based maximum power point tracking for photovoltaic power generation system. In: Proceedings of the 33rd annual IEEE power electronics specialists conference. pp 1489-1494

8. Noguchi T, Togashi S (2002) Short-current pulse based adaptive maximum-power-point tracking for a photovoltaic power generation system. Electr Eng Jpn 139:65-72

9. Lyden S, Haque ME (2015) Maximum power point tracking techniques for photovoltaic systems: a comprehensive review and comparative analysis. Renew Sustain Energy Rev 52:1504-1518

10. Farajdadian S, Hosseini SMH (2019) Design of an optimal fuzzy controller to obtain maximum power in solar power generation system. Sol Energy 182:161-178

11. Farajdadian S, Hosseini SMH (2019) Optimization Of Fuzzy-based MPPT Controller via Metaheuristic Techniques for Stand-alone PV Systems. Int J Hydrog Energy 44:25457-25472 
12. Seyedmahmoudian $M$, Horan $B$, Soon TK, Rahmani R, Than Oo AM, Mekhilef S, Stojcevski A (2016) State of the art artificial intelligence-based MPPT techniques for mitigating partial shading effects on PV systems e a review. Renew Sustain Energy Rev 64:435-455

13. Elobaid LM, Abdelsalam AK, Zakzouk EE (2015) Artificial neural network-based photovoltaic maximum power point tracking techniques: a survey. IET Renew Power Gener 9(8):1043-1063

14. Liu YH, Liu CL, Huang JW, Chen JH (2013) Neural-network-based maximum power point tracking methods for photovoltaic systems operating under fast changing environments. Sol Energy 89:42-53

15. Hosseini SMH, Keymanesh AA (2016) Design and construction of photovoltaic simulator based on dual-diode model. Sol Energy 137:594-607

16. Cabal C, Martínez-Salamero L, Séguier L et al (2014) Maximum power point tracking based on sliding-mode control for outputseries connected converters in photovoltaic systems. IET Power Electron 7(4):914-923

17. Southar M, Singh GK, Saini RP (2013) Comparison of mathematical models of photovoltaic (PV) module and effect of various parameters on its performance. In: ICEETS conference 2013. pp 1354-1359
18. Sharma P, Agarwal V (2014) Exact Maximum power point tracking of grid-connected partially shaded PV source using current compensation concept. IEEE Trans Power Electron 29(9):4684-4692

19. Bastidas-Rodriguez JD, Franco E, Petrone G, Andrés Ramos-Paja C, Spagnuolo G (2014) Maximum power point tracking architectures for photovoltaic systems in mismatching conditions: a review. IET Power Electron 7(6):1396-1413

20. Peter PK, Sharma P, Agarwal V (2012) Switched capacitor DCDC converter based current equalization scheme for maximum power extraction from partially shaded PV modules without bypass diodes. In: Proceedings of the 38th IEEE photovoltaic specialists conference (PVSC). pp 1422-1427

21. De Debnath DP, Chatterjee K (2016) Simple scheme to extract maximum power from series connected photovoltaic modules experiencing mismatched operating conditions. IET Power Electron 9(3):408-416

Publisher's Note Springer Nature remains neutral with regard to jurisdictional claims in published maps and institutional affiliations. 